PACS: $28.41 . \mathrm{Bm}$

\title{
RESEARCH AND DEVELOPMENT OF NOVEL MATERIALS FOR ACCIDENT TOLERANT FUEL CLADDING OF NUCLEAR REACTORS
}

\author{
(D) Kostiantyn V. Lobacha,*, (D) Oleksandr S. Kuprina, DSergiy Yu. Sayenkoa, \\ Dictor M. Voyevodin a,b, (DIgor V. Kolodiy ${ }^{\mathrm{a}}$ \\ ${ }^{a}$ National Science Center "Kharkiv Institute of Physics and Technology" \\ 61108, Kharkiv, Ukraine \\ ${ }^{b}$ V.N. Karazin National University, 61022, Kharkiv, Ukraine \\ *Corresponding Author: lobach0709@gmail.com \\ Received October 5, 2020; revised October 30, 2020; accepted November 4, 2020
}

The paper describes the challenges and worldwide scientific studies aimed for the manufacturing of the fuel elements claddings tolerant to a loss of coolant accidents (Fukushima NPP, March 2011, Japan) for water-cooled reactors. The main research results obtained at NSC KIPT on the development of materials for fuel element claddings, tolerant to accidents with loss of coolant, are given. The structure and properties of the developed vacuum-arc chromium coatings were investigated. It is shown, that these coatings can be used as protective element for existing fuel claddings, made of zirconium alloys, in light-water reactors of the PWR and BWR types. Alloyed $\mathrm{SiC}$-based ceramic was developed to replace zirconium-based fuel claddings. It has been established that doping of $0.5 \mathrm{wt} \% \mathrm{Cr}$ into $\mathrm{SiC}$ leads to an increase in the ability to resist the formation of cracks (crack resistance) by $25-30 \%$. The effect of $\mathrm{Cr}$ alloying on the corrosion resistance of $\mathrm{SiC}$ ceramics under conditions, simulating the medium of the first circuit of the VVER-1000 reactor, is analyzed. It was established that doping of even a small amount of $\mathrm{Cr}$ leads to a slowdown in corrosion processes in SiC ceramics. In order to create new material for fuel elements claddings Fe-Cr-Al-based alloys with the doping of alloying elements (Y, $\mathrm{Zr}$ and $\mathrm{Mo}$ ) were also developed and studied. Obtained alloys showed high mechanical properties and resistance to high-temperature oxidation.

KEYWORDS: fuel elements cladding, corrosion, protective coatings, $\mathrm{SiC} / \mathrm{SiC}$ composites, $\mathrm{Fe}-\mathrm{Cr}-\mathrm{Al}$ alloys

The term "ATFC" (Accident Tolerant Fuel Cladding) for water-cooled reactors came into use after the Fukushima NPP accident in March, 2011, in Japan. At that time, at a distance of $130 \mathrm{~km}$ from the coastal area of Japan the grade $\approx 9.0$ earthquake took place, which caused the failure of NPP electric power lines, while the following earthquake wave flooded and put out of action emergency diesel generators, which were at lower levels of the NPP site. That resulted in the final and full NPP Station Blackout (SBO), and as a consequence, in the Loss-of-Coolant Accident [1]. Under this type of accidents, an intense heat generation continues in the nuclear reactor, accompanied with a temperature rise due the nuclear reactions in $\mathrm{UO}_{2}$ fuel pellets. At about $950{ }^{\circ} \mathrm{C}$, the reaction between the zirconium fuel-element cladding and steam, known as the steam-zirconium reaction, begins

$$
\mathrm{Zr}+2 \mathrm{H}_{2} \mathrm{O}=\mathrm{ZrO}_{2}+2 \mathrm{H}_{2}+Q
$$

At a temperature of $1200{ }^{\circ} \mathrm{C}$, this reaction starts to develop rapidly with great heat liberation, thus becoming a selfsustaining reaction, and that leads to fuel cladding melting (Fig. 1) [2]. Concurrent with heat liberation, a great amount of hydrogen is also released (cf., $\sim 0.5 l \mathrm{H}_{2}$ per one gram of reacting $\mathrm{Zr}$ ), which is accumulated inside the reactor and the reactor block, this inevitably leading to dangerously explosive situation.

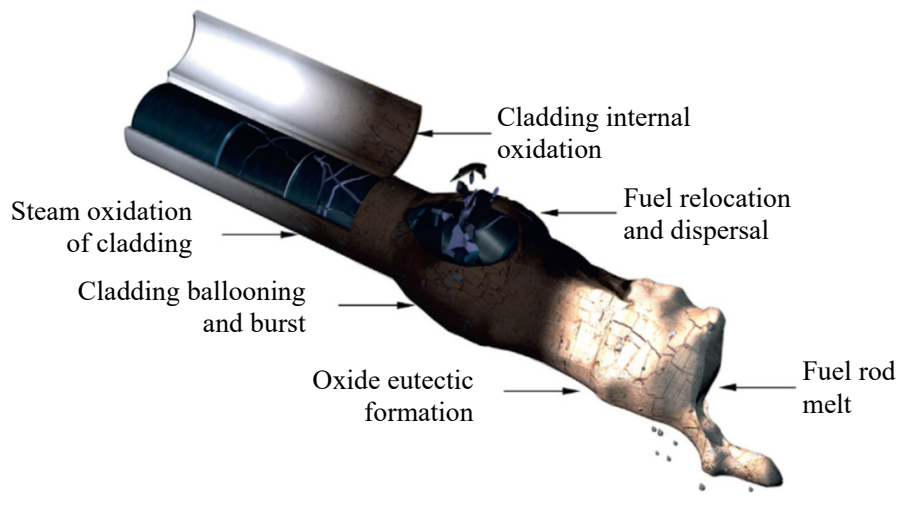

Figure 1. Evolution of a fuel rod under LOCA and SBO conditions [2]

To this date, it is common practice in the world to use for all water-cooled reactors the fuel claddings made of zirconium alloys (E110, M5, Zirlo, Zircaloy 4, etc.), and thus, the danger of hazardous consequences in case of loss-ofcoolant accidents (LOCA) still remains. The creation of ATFCs should substantially improve the safe use of modern nuclear-power engineering. 
Scientific studies into ATFC creation are carried out in different lines of research, and they differ in the term of their realization. The near-term technologies imply the application of protective coatings to the surfaces of existing zirconiumalloy claddings, whereas the mid-term technologies involve their complete replacement by claddings made from other materials such as metal alloys based on FeCrAl, Mo/FeCrAl, and SiC-base ceramic materials (Fig. 2 [3]).



Figure 2. Development of ATF fuel [3]

All these studies are aimed at reducing the cooling load during the LOCA by decreasing the heat-release rate and the total volume of liberated heat $(\mathrm{Q})$, which results from cladding oxidation under the action of high-temperature steam; that, in turn, reduces the rate of temperature rise. The slower increase of temperature retards the process of reaction (1) development, thereby providing some extra time for eliminating the accident and preventing its rapid development [4]. Therefore, the creation of ATFCs calls for the materials that show a considerably higher resistance to high-temperature steam oxidation than that of present-day zirconium claddings. Various R\&D programs to solve the problem [5,6] were initiated all over the world after the Fukushima accident. The undertaken studies have demonstrated that though the hightemperature steam is by far a more corrosive medium than dry $\mathrm{O}_{2}$ [7], still to protect zirconium alloys, oxide films can be used. The films must be oxidation resistant in the high-temperature steam, and also, must be physically and chemically stable, serving as barriers, which restrict solid-phase diffusion between the base material and $\mathrm{O}, \mathrm{OH}$ and $\mathrm{H}_{2} \mathrm{O}$. These properties are exhibited by three classes of protective films, namely, chromium oxide, alumina and silica [8].

Although zirconium oxide exhibits exceptional thermodynamic stability in the steam, however at $\mathrm{T}>1100{ }^{\circ} \mathrm{C}$ it readily transmits oxygen, letting the base metal (zirconium) be unprotected. On the other hand, chromium oxide, aluminium oxide, and silicium oxide show acceptable stability in high-temperature steam; they can react with the steam and evaporate at higher temperatures [9-11], acting, though slowly, as efficient barriers for diffusion of reaction products (oxygen and hydrogen). The oxidation rate of these films is approximately two orders of magnitude lower. This reduction of oxidation rate directly leads to the decrease in the rate of heat/hydrogen generation in water-cooled reactors at LOCAtype accident.

The present paper offers a short survey of research data obtained at the NSC KIPT, concerned with two directions in creation of ATF claddings, being actively developed in various international programs.

\section{COATINGS FOR FUEL CLADDINGS}

The evident and developmental approach to creating the ATFC lies in applying protective coatings to the surface of zirconium-alloy claddings. It is expected that thin coatings will have the minimal effect on the thermomechanical behavior of Zr-based cladding [12], and have the potential to improve the cladding heat transfer characteristics. The coatings are required to have the maximal adhesion to the cladding material and to be chemically stable with the cladding when in normal service in water $\left(\mathrm{T}=350{ }^{\circ} \mathrm{C}, \mathrm{P}=15 \mathrm{MPa}\right)$ of the primary coolant circuit of the reactor, and also, they should protect the cladding against rapid oxidation under LOCA-type conditions. As mentioned above, chromium, aluminium and silicium oxides are the materials that are capable to show resistance to oxidation in the high-temperature steam. For this reason, any protective coating of the ATF cladding must include at least one of the elements: $\mathrm{Cr}, \mathrm{Al}$ or $\mathrm{Si}$. The protective coatings must have the radiation resistance as good as that of the zirconium cladding, on which they are deposited.

The experimental studies have demonstrated that among a wide range of protective coatings applied to zirconium alloys by different methods, it is the chromium coatings produced by the PVD method that show the best protective properties [13-14].

Among other PVD methods, the vacuum-arc method of coating deposition has an essential advantage, viz., a high degree of deposited material ionization, which is favorable for obtaining relatively thin ( $\sim 10$ to $20 \mu \mathrm{m})$ high-adhesive coatings without through pores. This method makes it possible to produce nanostructural multilayer coatings, including ceramic coatings, at the deposition temperature that does not exceed the finishing treatment temperature of zirconiumalloy claddings $\left(\sim 450{ }^{\circ} \mathrm{C}\right)$, thereby precluding the occurrence of structural changes in the made fuel elements, and also without sacrificing their mechanical properties at test temperatures of 20 and $350{ }^{\circ} \mathrm{C}$ [15-17]. 
Comprehensive studies are carried out at the NSC KIPT to develop and deposit protective vacuum-arc coatings onto fragments of zirconium-alloy fuel tubes, as well as to investigate their influence on the mechanical properties at different temperatures [15-17], oxidation resistance [18-20] and hydrogen saturation [21, 22]. Studies are also made to investigate the radiation resistance of chromium coatings [23].

The $10 \mu \mathrm{m}$ thick multilayer $\mathrm{Cr} / \mathrm{CrN}$ and Cr coatings, developed at NSC KIPT, substantially slow down the oxidation rate of zirconium alloys in both the air and water steam at a temperature of $1100{ }^{\circ} \mathrm{C}$ over a period of no less than $3600 \mathrm{~s}$. The air-oxidation resistance of coatings on the $\mathrm{E} 110$ and $\mathrm{Zr} 1 \mathrm{Nb}$ alloys at test temperatures ranging from 660 to $1100{ }^{\circ} \mathrm{C}$ is independent of the alloy type and phase transformations in zirconium. The high resistance of the developed coatings is determined by the formation of a dense chromium-oxide layer on their surfaces (Fig. 3) [18-20].

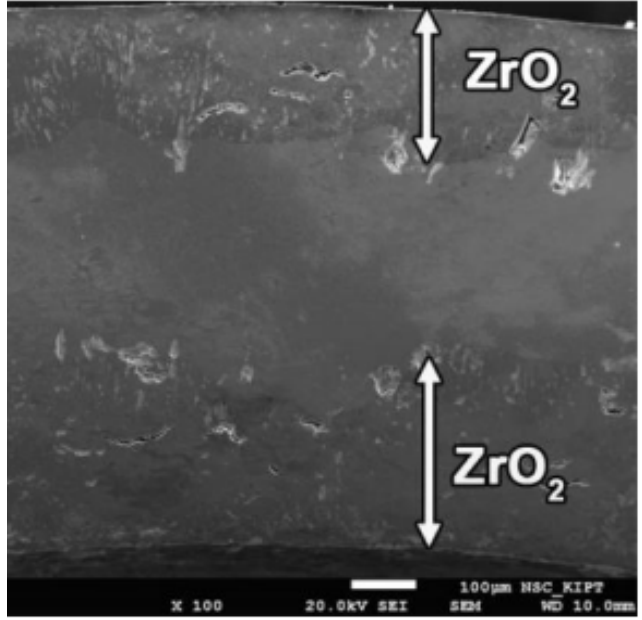

a

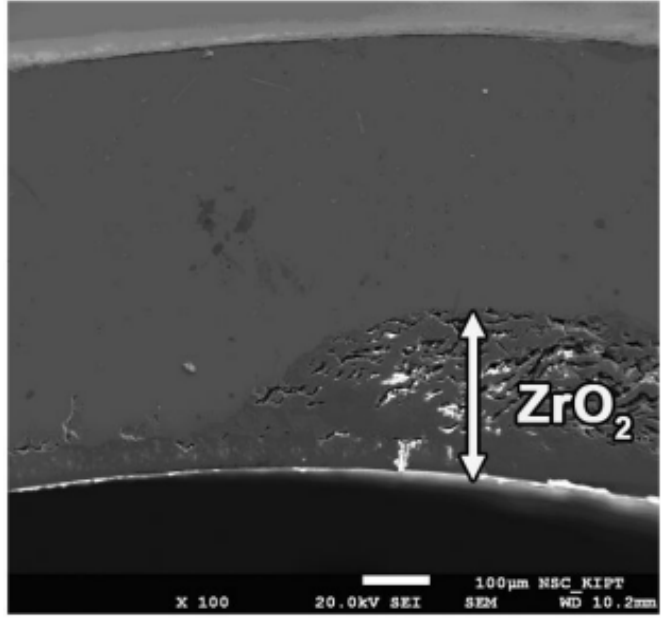

b

Figure 3. Electron microscope images of metallographic sections of E110 tubes after air oxidation at $1100{ }^{\circ} \mathrm{C}$ during $3600 \mathrm{~s}$ : a)uncoated, b) with protective $\mathrm{Cr}$ coating $(10 \mu \mathrm{m})[20]$

It has been established in Refs. $[21,22]$ that at the test temperatures ranging from $350{ }^{\circ}$ to $550{ }^{\circ} \mathrm{C}$, and at test pressures of hydrogen (deuterium) between 0.01 and $0.8 \mathrm{~Pa}$, the $\mathrm{Cr}$ and $\mathrm{Cr} / \mathrm{CrN}$ coatings under study present a reliable barrier to hydrogen penetration, and protect zirconium from hydride accumulation.

The radiation resistance of chromium coatings was investigated by the TEM methods after their irradiation in the ESU-2 accelerator by $1.4 \mathrm{MeV} \mathrm{Ar}{ }^{+}$ions at a temperature of $400^{\circ} \mathrm{C}$ in the dose range from 5 to $25 \mathrm{dpa}$ [23]. The vacuumarc chromium coatings in the output state show a sub-microcrystalline structure with an average grain size of $\sim 250 \mathrm{~nm}$. Inside the grains there are dislocations of density $\sim 8 \times 10^{14} \mathrm{~m}^{-2}$. The electron-diffraction pattern of chromium coating shows textured maxima in the form of points, this being indicative of the oriented growth of some grains. Adjacent to the points, there are the maxima in the form of round brackets, which attest to the presence of grains of random orientation.

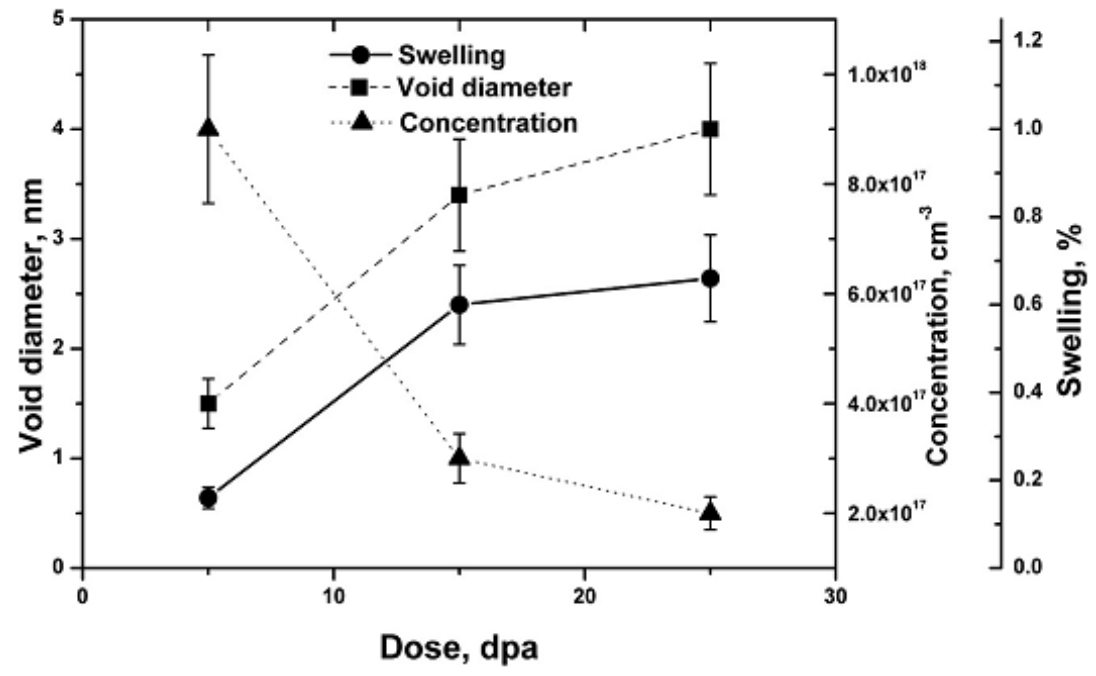

Figure 4. Dose dependence of average size, concentration of voids and swelling in irradiated Cr coatings [23]

Under exposure to a dose of $5 \mathrm{dpa}$, the radiative swelling of chromium coatings has been found to be $\sim 0.16 \%$, and with a dose increase up to $25 \mathrm{dpa}$, it attains $0.66 \%$ (Fig. 4), this pointing to a high radiation resistance of the developed chromium coatings. 
The given research results demonstrate that the vacuum-arc chromium coatings can be used to provide corrosion and oxidation protection of zirconium-alloy claddings for water-cooled reactors of PWR and BWR types.

\section{SiC-BASED FUEL CLADDINGS}

The SiC-based materials exhibit such attractive properties as high-temperature oxidation resistance [8], hightemperature chemical stability, strength and resistance to radiation damage, which make these materials most promising for applying as ATFC in water-cooled reactors. At present, the R\&D world activities in production of SiC-based claddings are mainly performed in two separate directions using:

1. The Chemical Vapor Infiltration (CVI) method being the most common approach in the world to cladding production. The method includes the vapor-phase deposition of $\mathrm{SiC}$ onto $\mathrm{SiC}$ fibers that results in production of highpurity crystalline $\mathrm{SiC}$ composite showing a high radiation resistance but a relatively low density (porosity being 10 to $25 \%)[24,25]$.

2. The Nano-Infiltration and Transient Eutectic-phase (NITE) method, mainly used in Japan, involves the infiltration of SiC-fiber with $\beta$-SiC nanopowder with a further use of the hot pressing (HP) technique to produce the claddings made of $\mathrm{SiC} / \mathrm{SiC}$ composite. The method ensures the production of high-density material with improved physical-mechanical properties [26, 27].

The NSC KIPT scientists are involved in the development of SiC-based materials using the high-speed hot pressing (HSHP) method [28], and also, in the studies into the influence of alloying additives on the mechanical characteristics of produced materials [29] and the SiC-based materials corrosion-resistance under hydrothermal conditions [30].

The studies in ref. [28] were aimed to establish optimum process parameters for producing the high-density SiC ceramics by the HSHP method. The method is based on passing directly the current through the press mold and the material sintered, and has an essential advantage over the HP method for the sintering rate (up to $400{ }^{\circ} \mathrm{C} / \mathrm{min}$.). Thus, during rapid heating, the process of sintering instantaneously passes through the low-temperature stage with usual dominance of the mechanisms of grain growth, and goes to the high-temperature stage, now with the dominance of densification mechanisms. Besides, the concentration of heat evolution on the particle surface causes the melting of surface layers and the destruction of oxide films with the result that chemical reactions get accelerated [31].

Figure 5 shows the cleavage structures of $\mathrm{SiC}$ ceramics produced at non-optimal/optimal process parameters of the HSHP method (Figs. 5a and 5b, respectively). It is found that the best physical-mechanical properties of SiC ceramics are attained at the sintering temperature $\mathrm{T}=2050{ }^{\circ} \mathrm{C}$, pressure $\mathrm{P}=40 \mathrm{MPa}$ and the holding-pressure time $\mathrm{t}=30 \mathrm{~min}$. The obtained ceramics exhibits a high density (up to $99.4 \%$ of the theoretical value), the hardness $27.3 \pm 0.5 \mathrm{GPa}$, and the monolithic and homogeneous structure with clear-cut grain boundaries and with the signs of brittle failure (Fig. $5 \mathrm{~b}$ ).



a

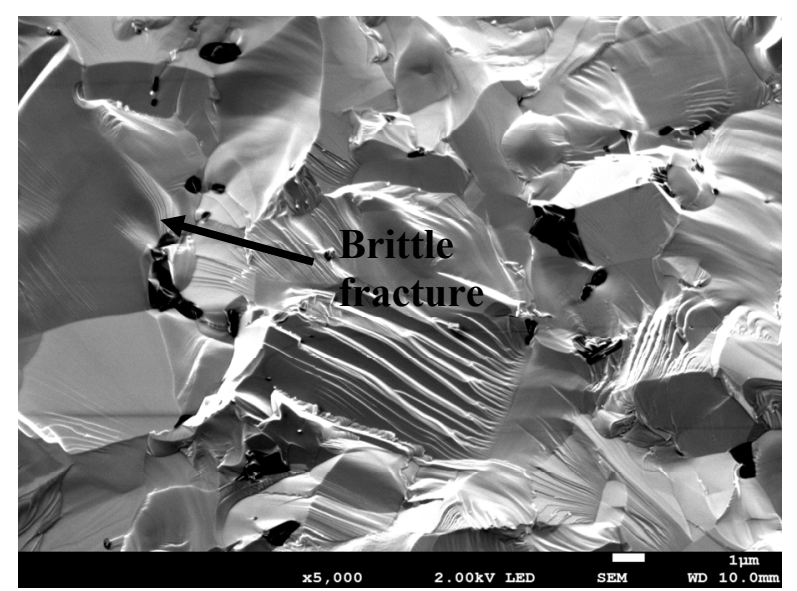

b

Figure 5. Microstructure of SiC ceramics cleavage: a - non-optimal parameters, b - optimal parameters of the HSHP method [29]

Paper [29] is concerned with the improvement of physical-mechanical properties of SiC through introduction of different alloying additives (Table 1).

Table 1.

Hardness and fracture toughness values of $\mathrm{SiC}$

\begin{tabular}{|l|c|c|c|c|}
\hline \multicolumn{1}{|c|}{ Samples } & Density, $\mathrm{g} / \mathrm{cm}^{3}$ & Open porosity, $\%$ & $\begin{array}{c}\text { Hardness } \mathrm{H}_{\mathrm{v}}, \\
\mathrm{GPa}\end{array}$ & $\begin{array}{c}\text { Crack growth resistance } \\
\mathrm{K}_{\mathrm{lc}}, \mathrm{MPa} \cdot \mathrm{m}^{1 / 2}\end{array}$ \\
\hline $\mathrm{SiC}$ & 3.19 & 0 & 27.3 & 4.3 \\
\hline $\mathrm{SiC}+\mathrm{Cr}$ & 3.16 & $0-1$ & 28.0 & 6.2 \\
\hline $\mathrm{SiC}+\mathrm{Si}$ & 3.18 & $0-1$ & 30.0 & 4.7 \\
\hline
\end{tabular}


As is seen from the given data, at similar values of density, open porosity and hardness, the fracture toughness values have increased in the samples with $\mathrm{Cr}$ and $\mathrm{Si}$ additions. For example, the fracture toughness parameters increase from $\mathrm{K}_{1 \mathrm{c}}=4.3 \mathrm{MPa} \cdot \mathrm{m}^{1 / 2}$ for the $\mathrm{SiC}$ ceramic samples up to $\mathrm{K}_{1 \mathrm{c}}=6.2 \mathrm{MPa} \cdot \mathrm{m}^{1 / 2}$ for the $\mathrm{SiC}$ samples with $\mathrm{Cr}$ additions. Figure 6 demonstrates the influence of the $\mathrm{Cr}$ addition on the coefficient of fracture toughness. Thus, at the same load of $9.81 \mathrm{~N}$, one can see that in the $\mathrm{SiC}$ sample with $\mathrm{Cr}$ additions (Fig. 6b) no noticeable cracks are observed, whereas in the pure $\mathrm{SiC}$ sample (Fig. 6a) the cracks do exist.


Figure 6. Effect of $\mathrm{Cr}$ on the coefficient of fracture toughness of $\mathrm{SiC}$ $\mathrm{a}$ - pure $\mathrm{SiC}, \mathrm{b}-\mathrm{SiC}$ with $\mathrm{Cr}$ additions [30]

Obtained results may have a substantial effect on the production technology of $\mathrm{SiC}$-matrix in $\mathrm{SiC} / \mathrm{SiC}$ composites for manufacturing the fuel element claddings since there is a problem of manufacturing thin-walled tubes (claddings) from a brittle $\mathrm{SiC}$ ceramics, which has low values of the fracture toughness coefficient.

Experiments were made in [30] to investigate the behavior of $\mathrm{SiC}$ ceramics under hydrothermal conditions. It is known that in spite of corrosive resistance in a high-temperature steam, the SiC-based ceramics dissolves in hightemperature water, i.e., under conditions of non-emergency service in water-cooled reactors. The possibility was demonstrated to exist for the radionuclides to release from the nuclear fuel through the fuel element cladding to the coolant due to the occurrence of hydrothermal corrosion and microcracks [32]. The undertaken research suggests that for decreasing the rate of $\mathrm{SiC}$ dissolution under hydrothermal conditions, the methods should be developed for alloying of anticorrosive additives, and also, for use of corrosion-resistant coatings, or both methods in combination [33, 34].

As indicated above, the best corrosion-resistance data were obtained for the coatings based on Cr. This element is used in the development of metal alloys based on $\mathrm{FeCrAl}$ and $\mathrm{Mo} / \mathrm{FeCrFl}$, which exhibit high corrosion resistance [8]. Besides, $\mathrm{Cr}$ is used for improving the corrosion resistance in steels, e.g., the introduction of no less than $12 \% \mathrm{Cr}$ into the alloy drastically increases the corrosion resistance (stainless steel). Taking this into account, $\mathrm{Cr}$ was chosen in [30] as the main anticorrosion alloying additive.

Table 2 and the plots (Fig. 7) give the hydrothermal corrosion test data for the $\mathrm{SiC}$ samples (without/with $\mathrm{Cr}$ and $\mathrm{Si}$ additives) produced by the HSHP method at a water temperature of $350{ }^{\circ} \mathrm{C}$ and a pressure of $16.8 \mathrm{MPa}$. After 100 hours of holding time, the $\mathrm{SiC}$ samples with $\mathrm{Cr}$ additives exhibited the increase in mass per area of $\sim 3.27 \mathrm{mg} / \mathrm{dm}^{2}$. At that, the masses of $\mathrm{SiC}$ samples with and without additives get decreased. Then, the mass reduction is observed in the samples with $\mathrm{Cr}$ additions, too. However, as it can be seen from the plot (Fig. 6), the best corrosion resistance under hydrothermal test conditions was shown by the $\mathrm{SiC}$ ceramics with $\mathrm{Cr}$ additions.

Table 2.

Corrosion test results for $\mathrm{SiC}$ samples

\begin{tabular}{|c|c|c|c|}
\hline $\begin{array}{c}\text { Test duration } \\
\text { (hours) }\end{array}$ & $\begin{array}{c}\mathrm{SiC}+\mathrm{Cr}, \\
\mathrm{mg} / \mathrm{dm}^{2}\end{array}$ & $\begin{array}{c}\mathrm{SiC}, \\
\mathrm{mg} / \mathrm{dm}^{2}\end{array}$ & $\begin{array}{c}\mathrm{SiC}+\mathrm{Si}, \\
\mathrm{mg} / \mathrm{dm}^{2}\end{array}$ \\
\hline 0 & 0 & 0 & 0 \\
\hline 100 & 3.27 & -4.01 & -2.74 \\
\hline 350 & -3.07 & -7.27 & -4.96 \\
\hline 600 & -5.42 & -8.27 & -7.20 \\
\hline 1000 & -8.49 & -12.53 & -10.66 \\
\hline
\end{tabular}

Some teams of scientists who investigated the hydrothermal corrosion of silicon carbide [35, 36], have indicated that the following thermodynamic reactions may occur between $\mathrm{SiC}$ and water:

$$
\begin{aligned}
& \mathrm{SiC}+2 \mathrm{H}_{2} \mathrm{O} \rightarrow \mathrm{SiO}_{2}+\mathrm{CH}_{4} ; \\
& \mathrm{SiC}+4 \mathrm{H}_{2} \mathrm{O} \rightarrow \mathrm{SiO}_{2}+\mathrm{CO}_{2}+4 \mathrm{H}_{2} \\
& \mathrm{SiC}+3 \mathrm{H}_{2} \mathrm{O} \rightarrow \mathrm{SiO}_{2}+\mathrm{CO}+3 \mathrm{H}_{2} \\
& \mathrm{SiC}+2 \mathrm{H}_{2} \mathrm{O} \rightarrow \mathrm{SiO}_{2}+\mathrm{C}+2 \mathrm{H}_{2}
\end{aligned}
$$




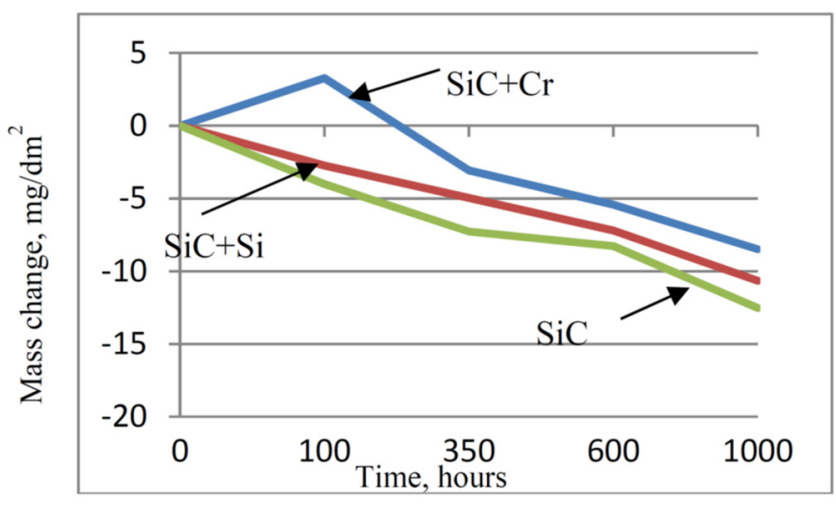

Figure 7. Results of corrosion tests of SiC samples [31]

As is obvious, by reactions (2) to (5), protective $\mathrm{SiO}_{2}$ films are formed on the $\mathrm{SiC}$ surface. On this basis, the corrosion resistance difference can be explained by the formation of corrosion-resistant products $\left(\mathrm{Cr}_{2} \mathrm{O}_{3}\right.$, and $\left.\mathrm{Cr}_{n} \mathrm{C}_{\mathrm{x}}\right)$, which have a substantial effect on the capacity of $\mathrm{SiO}_{2}$ films for passivation of sample surfaces.

Relying on the obtained data, it can be argued that the presence of even minor $\mathrm{Cr}$ additives content radically changes the behavior of the ceramics during oxidation, and leads to the formation of more corrosion-resistant protective $\mathrm{SiO}_{2}$ films on the $\mathrm{SiC}$ sample surfaces with $\mathrm{Cr}$ additives, essentially reducing the corrosion under hydrothermal conditions.

\section{FE-CR-AL-BASED ALLOYS AS A MATERIAL FOR FUEL CLADDINGS}

$\mathrm{Fe}-\mathrm{Cr}$-Al based alloys are considered within the ATFC concept as one of the possible options for replacing traditional zirconium alloys for nuclear fuel claddings after the accident at the Japanese nuclear power plant Fukushima [8, 37]. These alloys have increased oxidation resistance (and, as consequence, reduced hydrogen accumulation) and higher strength compared to zirconium alloys, at least up to $1300{ }^{\circ} \mathrm{C}$. A distinctive feature of Fe-Cr-Al based alloys is the formation of a thin protective alumina film during the high-temperature tests in water vapor [7] and high corrosion resistance during tests under conditions close to the normal operation, due to the formation of a spinel film from chromium and iron oxides [38]. In addition, the advantage of these alloys relative to the corrosion-resistant austenitic steels is the absence of nickel, the presence of which is undesirable in materials for thermal neutron reactors [39]. These alloys also satisfy the requirements for fuel cladding materials in terms of the complex of neutron-physical characteristics and radiation resistance $[40,41]$.

The study of the effect of alloying elements (Y, Mo and Zr) on the structure, heat resistance, physical and mechanical properties of alloys based on the Fe-Cr-Al system was carried out at NSC KIPT [42]. Six alloys (No. 1 - No. 6) were selected as materials for the study, two of which (No. 1 and No. 2) were industrial Kanthal alloys grade X23U5T: No. 1 - Kanthal alloy, grade X23U5T; No. 2 - Kanthal alloy after remelting; No. 3 - 72.5Fe-21Cr-6Al-0.5Y; No. 4 - 72Fe-21Cr-6Al-1Y; No. 5 - 70Fe-21Cr-6Al-1Y-2Mo; No. 6 - 63Fe-23Cr-9Al-1Y-2Mo-2Zr (all values are in wt \%). XRD analysis showed that all alloys were single-phase (except the alloy No. 6) and consisted of a bcc phase (Fig.8a). It was established that molybdenum is uniformly distributed over the alloy, while yttrium is concentrated at grain boundaries and in oxide precipitations. Alloying Kanthal with $2 \% \mathrm{wt}$ zirconium leads to the formation of a microstructure which consists of grains of the matrix bcc phase and intergranular eutectic "BCC matrix phase + $\mathrm{FCC}$ Laves phase $\mathrm{ZrFe} 2$ ". The main amount of yttrium and zirconium is concentrated in the eutectic.
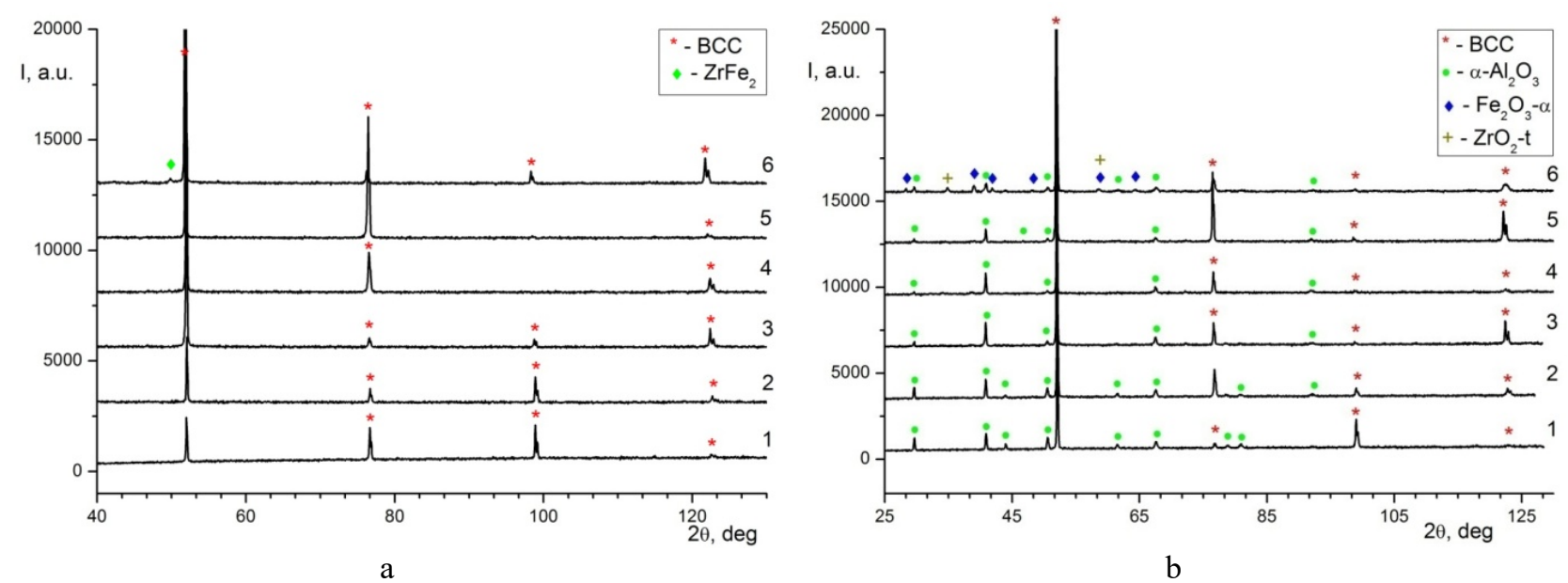

Figure 8. Diffraction patterns of $\mathrm{Fe}-\mathrm{Cr}-\mathrm{Al}$ alloys: a) initial state; b) after oxidation in air at $\mathrm{T}=1300{ }^{\circ} \mathrm{C}$ for 3 hours 
The effect of the alloys composition on their resistance to high-temperature oxidation was investigated by annealing in the furnace in air at temperature $\mathrm{T}=1300^{\circ} \mathrm{C}$ for 3 hours and atmospheric pressure. The results of this study are shown in Fig. 9.

All samples after high-temperature oxidation tests showed an increase in weight without shedding (peeling) with the formation of a dense dark-gray oxide film on the surface (Fig.10). The lowest mass gain $\left(0.3 \mathrm{mg} / \mathrm{cm}^{2}\right)$ was observed in the samples doped with Y and Mo, and the highest $\left(7.2 \mathrm{mg} / \mathrm{cm}^{2}\right)$ - in the samples doped with Y, Mo and Zr. Such different behavior of alloys during oxidation is associated with the formation of oxide layers of different phase composition on their surface. According to the X-ray diffraction analysis all samples consist of bec matrix phase and alumina $\mathrm{Al}_{2} \mathrm{O}_{3}-\alpha$ (Fig.8b). Diffraction pattern of the alloy No. 6 (which shows the lowest stability) also revealed the presence of hematite $\mathrm{Fe}_{2} \mathrm{O}_{3}-\alpha$ and tetragonal zirconia $\mathrm{ZrO}_{2}-\mathrm{t}$ in addition to the bcc phase and $\mathrm{Al}_{2} \mathrm{O}_{3}-\alpha$. I.e., in this case, oxidation occurred not only of alloying elements but also of matrix elements.



Figure 9. Mass gain of the $\mathrm{Fe}-\mathrm{Cr}-\mathrm{Al}$ samples after oxidation in air at $\mathrm{T}=1300{ }^{\circ} \mathrm{C}$ for 3 hours



Figure 10. Appearance of the Fe-Cr-Al samples after high-temperature oxidation

Table 3 shows data on the mechanical properties of the investigated alloys. As it can be seen, alloying the $\mathrm{Fe}-\mathrm{Cr}-\mathrm{Al}$ alloys with various chemical elements affects their mechanical and wear-resistant properties. Parameters $\mathrm{H} / \mathrm{E}$ and $\mathrm{H}^{3} / \mathrm{E}^{2}$ are used to assess the wear resistance and resistance of materials to plastic deformation, respectively [43, 44]. Nanohardness, Young's modulus, microhardness and compressive yield strength decrease for alloys alloyed only with Y (samples No. 3 and No. 4). Additional alloying with molybdenum (sample No. 5) leads to an increase in nanohardness and microhardness. Simultaneous alloying with Y, Mo and Zr (sample No. 6) increases all mechanical characteristics of the alloy, and the parameters $\mathrm{H} / \mathrm{E}$ and $\mathrm{H}^{3} / \mathrm{E}^{2}$ are the highest among all the alloys under study.

Table 3.

Mechanical properties of the Fe-Cr-Al alloys ( $\rho$ - density, $\mathrm{H}$ - nanohardness, E - Young's modulus, $H_{\mu}^{200}$ - microhardness at load of $200 \mathrm{~g}, \sigma_{\mathrm{T}}-$ compressive yield strength, $\mathrm{V}_{\mathrm{S}}$ - cavitation failure rate)

\begin{tabular}{|c|c|c|c|c|c|c|c|c|}
\hline \multirow{3}{*}{ Sample No } & \multicolumn{9}{|c|}{ Mechanical properties } \\
\cline { 2 - 10 } & $\rho, \mathrm{g} / \mathrm{cm}^{3}$ & $\begin{array}{c}\mathrm{H}, \\
\mathrm{GPa}\end{array}$ & $\begin{array}{c}\mathrm{E}, \\
\mathrm{GPa}\end{array}$ & $\mathrm{H} / \mathrm{E}$ & $\mathrm{H}^{3} / \mathrm{E}^{2}, \mathrm{GPa}$ & $H_{\mu}^{200}, \mathrm{GPa}$ & $\begin{array}{c}\sigma_{\text {Tc }} \\
\mathrm{kg} / \mathrm{mm}^{2}\end{array}$ & $\begin{array}{c}\mathrm{V}_{\mathrm{S}} \cdot 10^{2}, \\
\mathrm{~mm}^{3} / \mathrm{year}^{2}\end{array}$ \\
\hline 1 & 6.8 & 3.6 & 230.6 & 0.016 & $8.8 \cdot 10^{-4}$ & 2.35 & 60.2 & 9.7 \\
\hline 2 & 7.13 & 3.7 & 218.7 & 0.017 & $1.1 \cdot 10^{-3}$ & 2.40 & 53.4 & 19.6 \\
\hline 3 & 7.2 & 3.3 & 220.6 & 0.015 & $7.4 \cdot 10^{-4}$ & 2.22 & 44.2 & 18.8 \\
\hline 4 & 6.82 & 3.4 & 217.5 & 0.016 & $8.3 \cdot 10^{-4}$ & 2.45 & 55.7 & - \\
\hline 5 & 6.93 & 3.7 & 219.4 & 0.017 & $1.1 \cdot 10^{-3}$ & 2.51 & 54.5 & 27.3 \\
\hline 6 & 6.56 & 4.9 & 215.6 & 0.023 & $2.5 \cdot 10^{-3}$ & 3.42 & 97.6 & 4.57 \\
\hline
\end{tabular}

Since the strength characteristics of Fe-Cr-Al-based alloys are not worse than those of zirconium alloys, the most important characteristic for using these alloys as reactor material is their resistance to high-temperature oxidation. According to this alloy No. 5 (70Fe-21Cr-6Al-1Y-2Mo) is the most promising among the alloys under study.

\section{CONCLUSIONS}

The paper provides a brief overview of the main directions on the R\&D of materials for fuel element claddings in the world and the research results on the development of materials for the ATFC at NSC KIPT:

- Developed chromium vacuum-arc coatings with a set of their properties can be used to provide protection against corrosion of fuel claddings made of zirconium alloys for water-cooled reactors of the PWR and BWR types and to prevent LOCA type accidents.

- Technical parameters for obtaining SiC ceramics by the VGP method with high physical and mechanical properties were optimized. It has been shown that alloying $\mathrm{SiC}$ ceramics with chromium leads to an increase in the crack resistance 
coefficient $\left(\mathrm{K}_{1 \mathrm{c}}\right)$ by $25-30 \%$ and slows down corrosion processes under hydrothermal conditions corresponding to the normal operation of water-cooled reactors. Obtained $\mathrm{SiC}$ based ceramics can be used as a $\mathrm{SiC}$ matrix in $\mathrm{SiC} / \mathrm{SiC}$ composites for the manufacturing of fuel element claddings.

- Experimental alloys based on Fe-Cr-Al alloyed with Y, Mo and Zr were developed, their structure, heat resistance, physical and mechanical properties were investigated. Studies have shown that these alloys can be a promising material for reactor fuel claddings to replace traditional zirconium alloys within the ATFC concept.

The results obtained at the NSC KIPT can be taken into account and applied to solve the problems of fuel claddings manufacturing for water-cooled reactors in the framework of the safe and sustainable development of nuclear energy in Ukraine.

\section{ORCID IDs}

Dostiantyn V. Lobach, https://orcid.org/0000-0002-9838-2259; (DOleksandr S. Kuprin, https://orcid.org/0000-0003-4293-4197; (1DSergiy Yu. Sayenko, https://orcid.org/0000-0002-2598-3598; (DVictor M. Voyevodin, https://orcid.org/0000-0003-2290-5313;

(DIgor V. Kolodiy, https://orcid.org/0000-0001-8598-9732

\section{REFERENCES}

[1] M. Holt, R.J. Campbell, and M.B. Nikitin, Fukushima Nuclear Disaster, (Congressional Research Service, 2012), pp. 12, https://fas.org/sgp/crs/nuke/R41694.pdf

[2] S.J. Zinklea, K.A.Terrani, J.C. Gehin, L.J. Ott, and L.L. Snead, Journal of Nuclear Materials, 448, 374-379 (2014), https://doi.org/10.1016/j.jnucmat.2013.12.005.

[3] B.-S. Shannon, Nuclear News, 57, 83-91 (2014), https://doi.org/10.2172/1122119.

[4] L.J. Ott, K.R. Robb, D. Wang, Journal of Nuclear Materials, 448, 520-533 (2014), https://doi.org/10.1016/j.jnucmat.2013.09.052.

[5] F. Goldner, Development Strategy for Advanced LWR Fuels with Enhanced Accident Tolerance, (US Department of Energy, 2012), pp. 15, https://pdfs.semanticscholar.org/1b46/39a7109a0b27791662c802743c4798c0b44f.pdf.

[6] Y.-H. Koo, J.-H. Yang, J.-Y. Park, K.-S. Kim, H.-G. Kim, D.-J. Kim, Y.-I. Jung, and K.-W. Song, Nuclear technology, 186(2), 295-304 (2014), https://doi.org/10.13182/NT13-89.

[7] B.A. Pint, K.A. Terrani, M.P. Brady, T. Cheng, and J.R. Keiser, Journal of Nuclear Materials, 440, 420-427 (2013), https://doi.org/10.1016/j.jnucmat.2013.05.047.

[8] K.A. Terrani, Journal of Nuclear Materials, 501, 13-30 (2018), https://doi.org/10.1016/j.jnucmat.2017.12.043.

[9] H.A. Mohd, and R. Othman, Advanced Materials Research, 402, 412-420 (2012), https://doi.org/10.4028/www.scientific.net/AMR.402.412.

[10] T. Amano, ECS Transactions, 25, 3-19 (2010), https://doi.org/10.1149/1.3315791.

[11] E.J. Opila, J. Am. Ceram. Soc. 86(8), 1238-1248 (2003), https://doi.org/10.1111/j.1151-2916.2003.tb03459.x.

[12] Y. Lee, J.I. Lee, and H.C. No, NET, 49, 1031-1043 (2017), https://doi.org/10.1016/j.net.2017.03.012.

[13] C. Tang, M. Stueber, H.J. Seifert, and M. Steinbrueck, Corros. Rev. 35, 141-165 (2017), https://doi.org/10.1515/corrrev-2017-0010.

[14] J. Bischoff, C. Delafoy, C. Vauglin, P. Barberis, C. Roubeyrie, D, Perche, D. Duthoo, F. Schuster, J.-C. Brachet, E.W. Schweitzer, and K. Nimishakavi, Nucl. Eng. Technol. 50(2), 223-228 (2018), https://doi.org/10.1016/j.net.2017.12.004.

[15] V.A. Belous, P.N. V'jugov, A.S. Kuprin, S.A. Leonov, G.I. Nosov, V.D. Ovcharenko, L.S. Ozhigov, et al, PAST, 84(2), 140-143 (2013), https://vant.kipt.kharkov.ua/ARTICLE/VANT_2013_2/article_2013_2_140.pdf. (in Russian)

[16] L.S. Ozhigov, V.A. Belous, V.I. Savchenko, G.I. Nosov, V.D. Ovcharenko, G.N. Tolmachova, A.S. Kuprin, and V.S. Goltvyanitsa, PAST, 108(2), 168-172 (2017), https://vant.kipt.kharkov.ua/ARTICLE/VANT_2017_2/article_2017_2_168.pdf.

[17] P.I. Stoev, V.A. Belous, V.N. Voevodin, A.S. Kuprin, S.A. Leonov, V.D. Ovcharenko, M.A. Tihonovskij, V.M. Horoshih, PAST, 99(5), 87-97 (2015), https://vant.kipt.kharkov.ua/ARTICLE/VANT 2015 5/article 20155 87r.pdf. (in Russian)

[18] A.S. Kuprin, V.A. Belous, V.N. Voyevodin, V.V. Bryk, R.L. Vasilenko, V.D. Ovcharenko, G.N. Tolmachova, P.N. V'ygov, PAST, 89(1), 126-132 (2014), https://vant.kipt.kharkov.ua/ARTICLE/VANT_2014_1/article_2014_1_126.pdf.

[19] A.S. Kuprin, V.A. Belous, V.N. Voyevodin, V.V. Bryk, R.L. Vasilenko, V.D. Ovcharenko, E.N. Reshetnyak, G.N. Tolmachova, and P.N. V'yugov, Journal of Nuclear Materials, 465, 400-406 (2015), https://doi.org/10.1016/j.jnucmat.2015.06.016.

[20] A.S. Kuprin, V.A. Belous, V.V. Bryk, R.L. Vasilenko, V.N. Voyevodin, V.D. Ovcharenko, G.N. Tolmachova, et al, PAST, 96(2), 111-118 (2015), https://vant.kipt.kharkov.ua/ARTICLE/VANT_2015_2/article_2015_2_111.pdf.

[21] G.D. Tolstolutskaya, I.E. Kopanetz, V.V. Ruzhytskiy, V.A. Bilous, A.S. Kuprin, V.D. Ovcharenko, R.L. Vasilenko, and S.A. Leonov, PAST, 2015, 96(2), 119-123 (2015), https://vant.kipt.kharkov.ua/ARTICLE/VANT_2015_2/article_2015_2_118.pdf.

[22] I.E. Kopanetz, G.D. Tolstolutskaya, A.V. Nikitin, V.A. Belous, A.S. Kuprin, V.D. Ovcharenko, and R.L. Vasilenko, PAST, 99(5), 81-86 (2015), https://vant.kipt.kharkov.ua/ARTICLE/VANT_2015_5/article_2015_5_81.pdf.

[23] A.S. Kuprin, V.A. Belous, V.N. Voyevodin, R.L. Vasilenko, V.D. Ovcharenko, G.D.Tolstolutskaya, E. Kopanets, and V. Kolodiy, Journal of Nuclear Materials, 510, 163-167 (2018), https://doi.org/10.1016/j.jnucmat.2018.07.063.

[24] Y. Katoh, K. Ozawa, C. Shih, T. Nozawa, R.J. Shinavski, A. Hasegawa, and L.L. Sneada, Journal of Nuclear Materials, 448, 448-476 (2014), https://doi.org/10.1016/j.jnucmat.2013.06.040.

[25] O.A. Ageev, A.E. Beljaev, N.S. Boltovec, V.S. Kiselev, R.V. Konakova, A.A. Lebedev, V.V. Milenin, et al, Карбид кремния: технология, свойства, применение [Silicon carbide: technology, properties, applications], (Kharkiv, ISMA, 2010), pp. 532, http://isp.kiev.ua/images/Institute/lab33/Statti/SiCtechnologyPropertiesApplication.pdf. (In Russian)

[26] H.-W. Yu, P. Fitriani, S. Lee, J.-Y. Park, and D.-H. Yoon, Ceramics International, 41(6), $7890-7896$ (2015), https://doi.org/10.1016/j.ceramint.2015.02.127.

[27] Y. Katoh, A. Kohyama, T. Nozawa, and M. Sato, Journal of Nuclear Materials, 329-333, 587-591 (2004), https://doi.org/10.1016/j.jnucmat.2004.04.157.

[28] V. Voyevodin, S. Sayenko, K. Lobach, R. Tarasov, A. Zykova, Ye. Svitlychnyi, A. Surkov, et al, PAST, 108(2), 97-102 (2017), https://vant.kipt.kharkov.ua/ARTICLE/VANT_2017_2/article_2017_2_97.pdf. 
[29] K. Lobach, Y. Kupriiyanova, I. Kolodiy, S. Sayenko, V. Shkuropatenko, V. Voyevodin, A. Zykova, et al, Functional Materials, 25(3), 496-504 (2018), https://doi.org/10.15407/fm25.03.496.

[30] K.V. Lobach, S.Yu. Sayenko, V.A. Shkuropatenko, V.M. Voyevodin, H.V. Zykova, V.A. Zuyok, A.O. Bykov, et al, Materials Science, 55(5), 672-682 (2020), https://doi.org/10.1007/s11003-020-00358-5.

[31] D.O. Moskovskikh, Ph.D. Thesis, Получение субмикронного порошка карбида кремния и наноструктуированной керамики не его основе [Manufacturing of submicron silicon carbide powder and nanostructured ceramics on its basis], National University of Science and Technology MISiS, 2015. (In Russian)

[32] S. Kondo, M. Lee, T. Hinoki, Y. Hyodo, and F. Kano, Journal of Nuclear Materials, 464, 36-42 (2015), https://doi.org/10.1016/j.jnucmat.2015.04.034.

[33] V.A. Lavrenko, and Yu.G. Gogotsi, Коррозия конструкторской керамики [Corrosion of engineering ceramics], (Metallurgiya, Moscow, 1989), pp. 199. (In Russian)

[34] S.S. Raiman, P. Doyle, C. Ang, Y. Katoh, and K.A. Terrani, Corrosion, 75(2), 217 (2019), https://doi.org/10.5006/2997.

[35] H. Hirayama, T. Kawakubo, A. Goto, and T. Kaneko, J. Am. Ceram. Soc. 72, 2049-2053 (1989), https://doi.org/10.1111/j.11512916.1989.tb06029.x.

[36] E.J. Opila, N.S. Jacobson, D.L. Myers, E.H. Copland, The Journal of The Minerals, Metals \& Materials Society, (TMS). 58(1), 22-28 (2006), https://doi.org/10.1007/s11837-006-0063-3.

[37] Z. Duan, H. Yang, Y. Satoh, K. Murakami, S. Kano, Z. Zhao, J. Shen, and H. Abe, Nuclear Engineering and Design, 316, 131150 (2017), https://doi.org/10.1016/j.nucengdes.2017.02.031.

[38] K.A. Terrani, B.A. Pint, Y.-J. Kim , K.A. Unocic, Y. Yang, C.M. Silva, H.M. Meyer, and R.B. Rebak, Journal of Nuclear Materials, 479, 36-47 (2016), https://doi.org/10.1016/j.jnucmat.2016.06.047.

[39] B.A. Pint, K.A. Terrani, Y. Yamamoto, and L.L. Snead, Metallurgical and Materials Transactions E, 2, $190-196$ (2015), https://doi.org/10.1007/s40553-015-0056-7.

[40] X. Wu, T. Kozlowski, and J.D. Hales, Annals of Nuclear Energy, 85, 763-775 (2015), https://doi.org/10.1016/j.anucene.2015.06.032.

[41] K.G. Field, X. Hu, K.C. Littrell, Y. Yamamoto, and L.L. Snead, Journal of Nuclear Materials, 465, 746 - 755 (2015), https://doi.org/10.1016/j.jnucmat.2015.06.023.

[42] I I.V. Kolodiy, V.A. Belous, M.A. Bortnitskaya, R.L. Vasilenko, V.N. Voyevodin, V.I. Kovalenko, A.S. Kuprin, et al, Functional materials, 27(1), 79-86 (2020), https://doi.org/10.15407/fm27.01.79.

[43] A. Leyland, and A. Matthews, Wear, 246, 1-11 (2000), https://doi.org/10.1016/S0043-1648(00)00488-9.

[44] J. Musil, F. Kunc, H. Zeman, and H. Polakova, Surf. Coat. Technol. 154, 304-313 (2002), https://doi.org/10.1016/S02578972(01)01714-5.

\section{ДОСЛІДЖЕННЯ І РОЗРОБКА НОВИХ МАТЕРІАЛІВ ДЛЯ ПАЛИВНИХ ЕЛЕМЕНТІВ ЯДЕРНИХ РЕАКТОРІВ, СТІЙКИХ ДО АВАРІЙНИХ СИТУАЦІЙ}

К.В. Лобача, О.С. Купрін ${ }^{\mathrm{a}}$, С.Ю. Саєнко ${ }^{\mathrm{a}}$, В.М. Воєводін ${ }^{\mathrm{a}, \mathrm{b}}$, І.В. Колодій ${ }^{\mathrm{a}}$

${ }^{a}$ Національний науковий центр «Харківський фізико-технічний інститут», 61108, Харків, Украйна

${ }^{b}$ Харківський національний університет імені В.Н. Каразіна, 61022, Харків, Украӥна

В роботі показані світові наукові напрями по створенню оболонок тепловиділяючих елементів (ТВЭЛ) стійких до аварій із втратою теплоносія (АЕС Фукусіма, Японія, березень 2011 р.) для водо-охолоджуваних реакторів. Наведені основні результати досліджень отриманих в ННЦ ХФТІ, щодо створення матеріалів для оболонок ТВЕЛ стійких до аварій із втратою теплоносія. Досліджені структура та властивості розроблених вакуумно-дугових хромових покриттів, які можуть бути використані для захисту існуючих паливних оболонок із цирконієвих сплавів для легководних реакторів типу PWR та BWR. Розроблена легована кераміка на основі $\mathrm{SiC}$ для заміни паливних оболонок із цирконієвих сплавів. Встановлено, що введення $0,5 \% \mathrm{Cr}$ в $\mathrm{SiC}$ призводить до підвищення здатності чинити опір утворенню тріщин (тріщиностійкість) на $25-30 \%$. Проаналізовано вплив Cr на корозійну стійкість $\mathrm{SiC}$ кераміки в умовах, що імітують середу 1-го контуру реактора ВВЕР-1000. Встановлено, що введення навіть невеликої кількості $\mathrm{Cr}$ призводить до уповільнення корозійних процесів в $\mathrm{SiC}$ кераміці. 3 метою створення нових металевих паливних оболонок також були розроблені та досліджені сплави на основі $\mathrm{Fe}-\mathrm{Cr}-\mathrm{Al}$ з добавкою легуючих елементів (Y, Zr та Мо). Показано високі механічні властивості та стійкість отриманих сплавів щодо високотемпературного окислення.

КЛЮЧОВІ СЛОВА: оболонка паливних елементів, корозія, захисні покриття, $\mathrm{SiC} / \mathrm{SiC}$ композити, сплави $\mathrm{Fe}-\mathrm{Cr}-\mathrm{Al}$

\section{ИССЛЕДОВАНИЕ И РАЗРАБОТКА НОВЫХ МАТЕРИАЛОВ ДЛЯ ТОПЛИВНЫХ ЭЛЕМЕНТОВ ЯДЕРНЫХ РЕАКТОРОВ, СТОЙКИХ К АВАРИЙНЫМ СИТУАЦИЯМ}

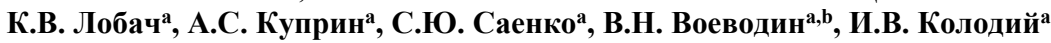

${ }^{a}$ Национальный научный центр «Харьковский физико-технический институт», 61108 Харьков, Украина

${ }^{b}$ Харьковский начиональный университет имени В.Н. Каразина, 61022, Харьков, Украина

В работе показаны мировые научные направления по созданию оболочек тепловыделяющих элементов (ТВЭЛ) устойчивых к авариям с потерей теплоносителя (АЭС Фукусима, Япония, март 2011 года) для водо-охлаждаемых реакторов. Приведены основные результаты исследований, полученных в ННЦ ХФТИ, по созданию материалов для оболочек ТВЭЛ, устойчивых к авариям с потерей теплоносителя. Исследованы структура и свойства разработанных вакуумно-дуговых хромовых покрытий, которые могут быть использованы для защиты существующих топливных оболочек с циркониевых сплавов для легководных реакторов типа PWR и BWR. Разработанная легированная керамика на основе $\mathrm{SiC}$ для замены топливных оболочек с циркониевых сплавов. Установлено, что введение $0,5 \% \mathrm{Cr}$ в $\mathrm{SiC}$ приводит к повышению способности сопротивляться образованию трещин (трещиностойкость) на 25 $30 \%$. Проанализировано влияние $\mathrm{Cr}$ на коррозионную стойкость $\mathrm{SiC}$ керамики в условиях, имитирующих среду 1-го контура реактора ВВЭР-1000. Установлено, что введение даже небольшого количества Сr приводит к замедлению коррозионных процессов в $\mathrm{SiC}$ керамике. С целью создания новых металлических топливных оболочек также были разработаны и исследованы сплавы на основе Fe-Cr-Al с добавкой легирующих элементов (Y, Zr и Мо). Показано высокие механические свойства и устойчивость полученных сплавов к высокотемперутурному окислению.

КЛЮЧЕВЫЕ СЛОВА: оболочка топливных элементов, коррозия, защитные покрытия, $\mathrm{SiC} / \mathrm{SiC}$ композиты, сплавы $\mathrm{Fe}-\mathrm{Cr}-\mathrm{Al}$ 